\title{
A New Electrolytic Production Process of Silicon Using Liquid Zn Alloy Cathode in Molten Salt
}

\section{AUTHOR(S):}

Nohira, Toshiyuki; Ido, Akifumi; Shimao, Takeyuki; Yang, Xiao; Yasuda, Kouji; Homma, Takayuki; Hagiwara, Rika

\section{CITATION:}

Nohira, Toshiyuki ...[et al]. A New Electrolytic Production Process of Silicon Using Liquid Zn Alloy Cathode in Molten Salt. ECS Transactions 2016, 75(15): 17-33

\section{ISSUE DATE:}

2016

URL:

http://hdl.handle.net/2433/236052

\section{RIGHT:}

() The Electrochemical Society, Inc. 2016. All rights reserved. Except as provided under U.S. copyright law, this work may not be reproduced, resold, distributed, or modified without the express permission of The Electrochemical Society

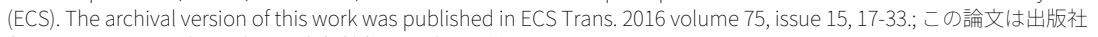
版でありません。引用の際には出版社版をご確認ご利用ください。; This is not the published version. Please cite only the published version. 


\title{
A New Electrolytic Production Process of Silicon Using Liquid Zn Alloy Cathode in Molten Salt
}

\author{
Toshiyuki Nohira ${ }^{\mathrm{a}}$, Akifumi Ido ${ }^{\mathrm{b}}$, Takeyuki Shimao ${ }^{\mathrm{b}}$, Xiao Yang \\ Kouji Yasuda,c, Rika Hagiwara ${ }^{\mathrm{a}}$ and Takayuki Homma ${ }^{\mathrm{d}}$ \\ a Institute of Advanced Energy, Kyoto University, Uji 611-0011, Japan. \\ ${ }^{\mathrm{b}}$ Graduate School of Energy Science, Kyoto University, Kyoto 606-8501, Japan \\ c Environment, Safety and Health Organization, Kyoto University, \\ Kyoto 606-8501, Japan \\ ${ }^{\mathrm{d}}$ Faculty of Science and Engineering, Waseda University, \\ Tokyo 169-8555, Japan.
}

Electrolytic production process for solar-grade Si utilizing liquid $\mathrm{Si}-\mathrm{Zn}$ alloy cathode in molten $\mathrm{CaCl}_{2}$ has been proposed. Toward the establishment of the process, the behavior of liquid $\mathrm{Zn}$ metal was investigated in molten $\mathrm{CaCl}_{2}$ at $1123 \mathrm{~K}$. The evaporation of $\mathrm{Zn}$ metal was largely suppressed by an immersion into molten salt, which enables the use of $\mathrm{Zn}$ electrode in spite of the high vapor pressure of $\mathrm{Zn}$. The cyclic voltammetry suggested the reduction of $\mathrm{SiO}_{2}$ at $1.45 \mathrm{~V}$ vs. $\mathrm{Ca}^{2+} / \mathrm{Ca}$ on a $\mathrm{Zn}$ cathode. After the potentiostatic electrolysis at $0.9 \mathrm{~V}$, Si particles with diameters of 2-30 $\mu \mathrm{m}$ were precipitated in the solidified $\mathrm{Zn}$ matrix by the slow cooling process of the produced liquid $\mathrm{Si}-\mathrm{Zn}$ alloy. The alloying rate between solid Si and liquid Zn was measured as $4.56 \mu \mathrm{m} \mathrm{s}^{-1}$, and it linearly decreased with the Si content in liquid $\mathrm{Zn}$ phase.

\section{Introduction}

Photovoltaic (PV) power generation has been developed as one of the key technologies that can mitigate the energy and environmental issues. For examples, there were several national projects in 1970s such as Sunshine Project by Ministry of International Trade and Industry (MITI) in Japan and Federal Photovoltaic Utilization Program by Department of Energy (DOE) in the United States. Since then, the situation has drastically changed in this decade; the increased installation of the PV cells promoted by the political and financial supports in various countries, the broadened usage from the conventional electronic calculator and independent power source to the large scale power station, and the diversification of the solar cell materials. Accordingly, the production volume of PV cells has increased in 21st century by a factor of more than 100; $285 \mathrm{MW}$ in 2000 and 36,100 MW in 2013 [1]. Non-silicon materials occupied only $0.4 \%$ of the production volume of solar cells in 2000, and reached $7.6 \%$ in 2013 because of the compound-type solar cells such as CdTe type and Cu-In-Ga-Se (CIGS) type [1].

As a matter of course, the PV cell installation will increase more and more in the future as one of the key technologies for environmental issues and diversification of energy source. In the light of the solar cell materials, compound-type solar cells have drawbacks for mass production because the production capacities are limited by the supply of the component materials obtained as byproducts in nonferrous metallurgy. For instance, the production capacity of CdTe solar cells are at most 6 to $8 \mathrm{GW}$ per year 
owing to the supply capacity of Te [2], and 20 to 30 GW for CIGS solar cells. Therefore, crystalline Si solar cells are most likely to be continuously a main stream of the PV industry in the long run.

High-purity Si used for crystalline Si solar cells are called as a solar-grade Si (SOG$\mathrm{Si}$ ), which exceeds the purity of $5 \mathrm{~N}-7 \mathrm{~N}$. Siemens process [3-6] utilizing $\mathrm{H}_{2}$ reduction and/or thermal decomposition of trichlorosilane $\left(\mathrm{SiHCl}_{3}\right)$, which is the current production process of SOG-Si, was originally developed for a manufacture of a semiconductor-grade Si (SEG-Si, 11N-12N purity) for large scale integrated circuits (LSIs). Due to the reaction kinetics of silane gases, Siemens process has inherent drawbacks of low productivity and low energy efficiency. To develop a next generation production process of SOG-Si, various types of production or refining processes of $\mathrm{Si}$, which can overcome the low productivity of the conventional Siemens process, have been investigated: $\mathrm{H}_{2}$ reduction and/or decomposition of silane-based gases in improved Siemens-based processes, metallothermic reduction of silicon halides by metal reductants such as zinc and aluminum, and purification of metallurgical-grade Si (MG-Si; 98-99\% purity) using metallurgical purification methods [7,8]. Recently, the fluidized bed reaction (FBR) of monosilane $\left(\mathrm{SiH}_{4}\right)$ in REC Silicon and SunEdison Samsung Fine Chemicals, and upgrading metallurgical-grade Si (UMG) using various refining techniques have been operated in a mass scale [9].

In our group, the direct electrolytic reduction of solid $\mathrm{SiO}_{2}$ to $\mathrm{Si}$ has been studied in molten $\mathrm{CaCl}_{2}$ at $1123 \mathrm{~K}$ as a new type of electrochemical reaction [10-12]. In this method, electrochemical reduction of insulating $\mathrm{SiO}_{2}$ proceeds by the use of a $\mathrm{SiO}_{2}$ contacting electrode which gives a three-phase interface between conductor $/ \mathrm{SiO}_{2} / \mathrm{molten}$ salt.

$$
\mathrm{SiO}_{2}(\mathrm{~s})+4 \mathrm{e}^{-} \text {(through conductor) } \rightarrow \mathrm{Si}(\mathrm{s})+2 \mathrm{O}^{2-}
$$

We also proposed that the combination of the electrolytic reduction of purified $\mathrm{SiO}_{2}$ and a directional solidification refinement is a potential method to realize the low-cost production of SOG-Si $[13,14]$. Recently, in order to improve the productivity of the process, we have studied the electrochemical reduction of $\mathrm{SiO}_{2}$ granules set on the bottom cathode in molten $\mathrm{CaCl}_{2}$ on the analogy of the Hall-Héroult Al production process [15]. By many research groups including us, the direct electrochemical reduction of $\mathrm{SiO}_{2}$ has been widely investigated for SOG-Si production [16-34]. However, the recovery of the powdery $\mathrm{Si}$ product from mixture of $\mathrm{Si}, \mathrm{SiO}_{2}$ and $\mathrm{CaCl}_{2}$ is one of challenges. Since the separation between solid product and molten salt is an inherent problem for molten salt processes, the cathodic products are usually manufactured in the liquid state for the easiness of the subsequent recovery in the practical production processes of $\mathrm{Li}, \mathrm{Na}, \mathrm{Mg}$, and $\mathrm{Al}$ metal, and rare earth alloys. Thus, we expected that a utilization of liquid Si alloy cathode would be a solution for the SOG-Si production process in molten $\mathrm{CaCl}_{2}$.

A typical recovery method of a certain metal from liquid alloy utilizes the principle of a solubility decrease upon temperature lowering. A well-known industrial process is the simultaneous metallurgical production of $\mathrm{Zn}$ and $\mathrm{Pb}$ called as the Imperial Smelting Process (ISP). When the liquid Si alloy cathode is applicable to the electrolytic reduction of $\mathrm{SiO}_{2}$ in molten salt, there are many advantages such as the easy separation of Si from molten salt and unreacted $\mathrm{SiO}_{2}$, and the easy transfer from the electrolysis cell. Further, since metallurgical-grade Si can be refined by a solidification of liquid Si alloys [35-49], 
high separation ability is expected in the Si precipitation process from liquid alloy, in which impurities are enriched in the liquid phase.

As an alloying element for $\mathrm{Si}$ which gives liquid alloy, $\mathrm{Zn}, \mathrm{Sn}, \mathrm{Pb}$, and $\mathrm{Al}$ are candidates because they have no intermetallic compounds with Si. Their characters are summarized in Table 1 [50-57]. Although Al looks promising due to the larger solubility at the electrolysis temperature, the removal of Al soluted in Si phase is difficult even to $100 \mathrm{ppm}$, which were reported in the electrolysis of $\mathrm{SiO}_{2}$ on $\mathrm{Al}$ cathode [28] and the refining of low-purity Si utilizing $\mathrm{Si}-\mathrm{Al}$ alloy [35-39]. Considering many factors, we selected $\mathrm{Zn}$ as an alloying element because the lower boiling point and smaller distribution coefficients are advantageous for obtaining high-purity Si products after vacuum refining and directional solidification in the final step.

Table 1 Properties of alloying elements for Si.

\begin{tabular}{ccccc}
\hline Metal & $\begin{array}{c}T_{\text {m.p. }} \\
/ \mathrm{K}\end{array}$ & $\begin{array}{c}T_{\text {b.p. }} \\
/ \mathrm{K}\end{array}$ & $\begin{array}{c}\text { Solubility of Si } \\
\text { at } 1123 \mathrm{~K} \\
/ \mathrm{mol} \%\end{array}$ & $\begin{array}{c}\text { Distribution coefficient } \\
\text { at } T_{\text {m.p. }} \text { (Si) }\end{array}$ \\
\hline $\mathrm{Zn}$ & $693[48]$ & $1180[48]$ & $6.0[52]$ & $1 \times 10^{-5}[52]$ \\
\hline $\mathrm{Sn}$ & $505[51]$ & $2875[51]$ & $0.9[53]$ & $1.6 \times 10^{-2}[53]$ \\
\hline $\mathrm{Pb}$ & $601[48]$ & $2019[48]$ & $<0.2[54]$ & $2 \times 10^{-3}[56]$ \\
\hline $\mathrm{Al}$ & $933[48]$ & $2791[48]$ & $32.6[55]$ & $2 \times 10^{-3}[57]$ \\
\hline
\end{tabular}

Figure 1 shows a schematic illustration of the proposed process for SOG-Si production utilizing a liquid $\mathrm{Si}-\mathrm{Zn}$ alloy cathode in molten salt. The overall process is composed of three major processes: an electrolysis process, a precipitation process, and a refining process. In the electrolysis process, solid $\mathrm{SiO}_{2}$ is reduced to form $\mathrm{Si}-\mathrm{Zn}$ liquid alloy on the cathode.

$$
\mathrm{SiO}_{2}(\mathrm{~s})+\mathrm{Si}-\mathrm{Zn}(\text { (l, low Si conc. })+4 \mathrm{e}^{-} \rightarrow \mathrm{Si}-\mathrm{Zn}(\text {, high Si conc. })+2 \mathrm{O}^{2-}
$$

Figure 2(a) and 2(b) shows the whole range and Zn-rich side of the phase diagram for the $\mathrm{Si}-\mathrm{Zn}$ system [52], respectively. Here, the temperature and composition changes in the proposed process are indicated in Fig. 2(b) with the arrows. The solubility of Si in liquid $\mathrm{Zn}$ is 6 at\% at $1123 \mathrm{~K}$. The $\mathrm{Si}-\mathrm{Zn}$ liquid alloy produced at the bottom of the electrolysis cell is separated from the molten salt due to the density difference, and is transferred to the precipitation process. In the precipitation process, metallic $\mathrm{Si}$ is recovered by lowering the temperature.

$$
\mathrm{Si}-\mathrm{Zn}(\mathrm{l} \text {, high Si conc.) } \rightarrow \mathrm{Si}(\mathrm{s})+\mathrm{Si}-\mathrm{Zn}(\mathrm{l} \text {, low Si conc.) }
$$

When the temperature is lowered to $923 \mathrm{~K}$, the solubility is also lowered to 1 at\%-Si, thus, solid Si of 5 at\% with reference to $\mathrm{Zn}$ is recovered. After the precipitation process, the $\mathrm{Si}-\mathrm{Zn}$ alloy with low Si concentration is reused as the cathode in the electrolysis process. The produced Si is further transferred to the refining process. An ingot of SOG$\mathrm{Si}$ is manufactured by a directional solidification of the Si treated after leaching and vacuum refining.

This process is expected to have several advantages in terms of productivity and purification ability. In contrast to the Siemens process, the proposed process can be 
operated semi-continuously, which contributes to the high productivity. High purification efficiency is expected in the two-times segregation step; the deposition of solid Si from $\mathrm{Si}-\mathrm{Zn}$ liquid alloy in the precipitation, and the precipitation of solid Si from liquid Si in the refining processes. Low distribution coefficients for the impurity elements, which mean the high purification ability, are reported both for the precipitation from liquids of metallic Si [57] and alloys of Si-Al [35-39], Si-Cu [40,41], Si-Sn [42,44], Si-Fe [4547], $\mathrm{Si}-\mathrm{Ni}$ [48], and $\mathrm{Si}-\mathrm{Na}$ [49]. Furthermore, the remaining $\mathrm{Zn}$ can be easily removed to several ppms even by the evacuation techniques used more than 30 years ago [58]. More complete removal of $\mathrm{Zn}$ is possible by using the advanced vacuum refining technology.

\section{Electrolysis}

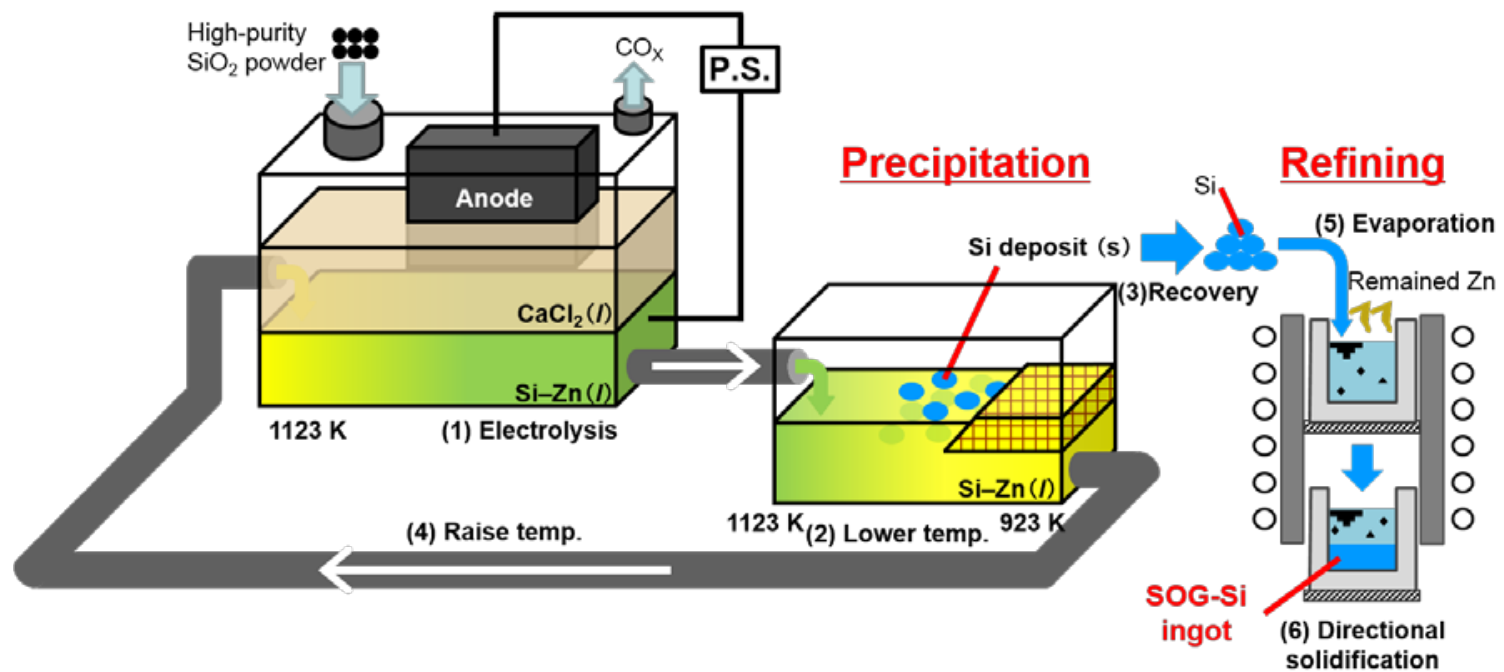

Figure 1. A schematic drawing of solar-grade Si production utilizing an electrochemical reduction of $\mathrm{SiO}_{2}$ powder on a liquid $\mathrm{Si}-\mathrm{Zn}$ alloy cathode in molten $\mathrm{CaCl}_{2}$.

(a)

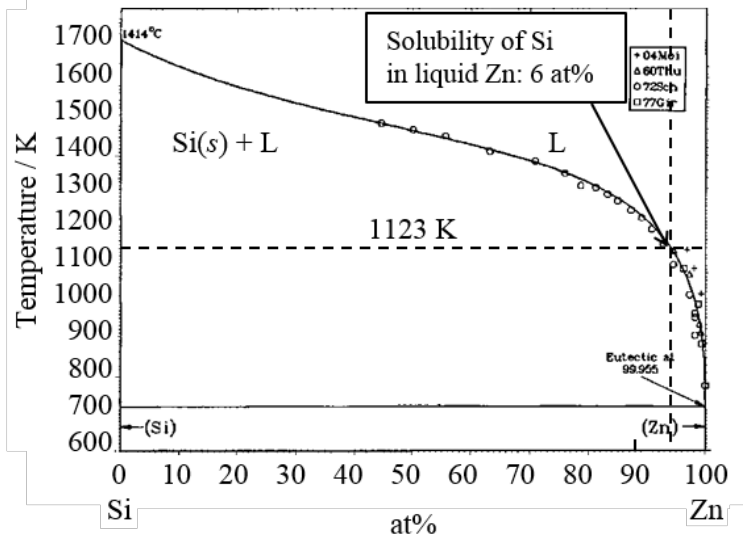

(b)

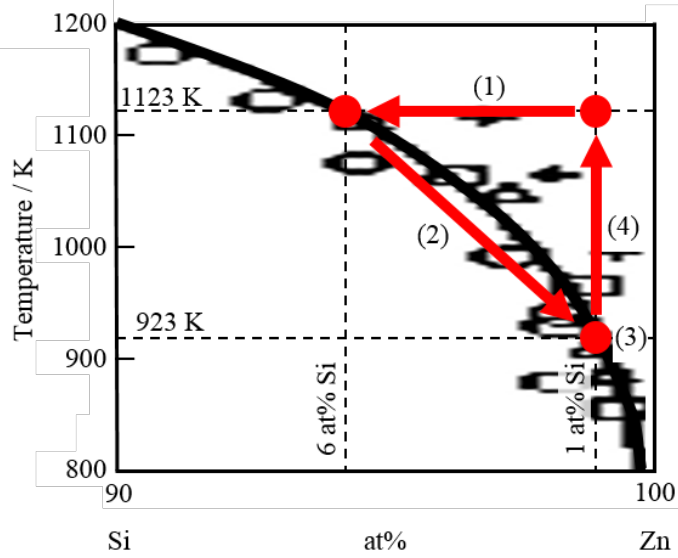

Figure 2. (a) A binary phase diagram for the Si-Zn system [52]. (b) Temperature and alloy composition in the production process.

(1) $\mathrm{SiO}_{2}$ is electrochemically reduced to liquid $\mathrm{Si}-\mathrm{Zn}$ alloy with $\mathrm{Si}$ concentration of 6.0 at $\%$ on the bottom cathode.

(2) Liquid 6.0at\% $\mathrm{Si}-\mathrm{Zn}$ alloy is recovered from the bottom of the electrolytic cell, and then cooled to $923 \mathrm{~K}$ to precipitate metallic Si corresponding to 5.0 at\% with respect to $\mathrm{Zn}$. 
(3) Precipitated metallic Si is recovered.

(4) Liquid 1.0 at\% $\mathrm{Si}-\mathrm{Zn}$ alloy is heated to $1123 \mathrm{~K}$ to reuse as the bottom cathode.

In this study, fundamentals on the electrolysis process, namely, the evaporation of $\mathrm{Zn}$ metal in molten $\mathrm{CaCl}_{2}$, the electrochemical reduction of $\mathrm{SiO}_{2}$ on $\mathrm{Zn}$ cathode, and alloying rate for the $\mathrm{Si}-\mathrm{Zn}$ system, were investigated at $1123 \mathrm{~K}$. The effect of immersion into molten $\mathrm{CaCl}_{2}$ on evaporation behavior of $\mathrm{Zn}$ metal was analyzed. Regarding the electrochemical behavior of liquid $\mathrm{Zn}$ electrode, Kipouos et al. reported the electrolysis of $\mathrm{Ca}-\mathrm{Zn}$ liquid alloy in molten $\mathrm{CaCl}_{2}-\mathrm{CaO}-\mathrm{CaF}_{2}$ system at $973-1023 \mathrm{~K}$ [59]. However, the electrode potential was unclear because the two-electrode system was employed. In the present study, we investigated the effective potential range for the production of $\mathrm{Si}-$ $\mathrm{Zn}$ alloy in the electrolysis of $\mathrm{SiO}_{2}$ granules on $\mathrm{Zn}$ electrode. Furthermore, the alloying rate was studied to estimate the rate-determining step on the electrochemical reaction on Zn electrode.

\section{Experimental}

\section{Evaporation of Zn}

The evaporation rate of $\mathrm{Zn}$ in an $\mathrm{Ar}$ atmosphere at $1123 \mathrm{~K}$ was measured by the weight change of Zn metal (Kojundo Chemical Laboratory Co., Ltd., 99.9999\%, grains, $5.4 \sim 5.6 \mathrm{~g}$ ) set at the bottom of a silica tube (outer diameter (o.d.); $12.5 \mathrm{~mm}$, inner diameter (i.d.); $10.5 \mathrm{~mm}$ ) with/without the addition of $\mathrm{CaCl}_{2}$ (Kojundo Chemical Laboratory Co., Ltd., 99\% up, 5.4 5.6 g or 8.2 8.4 g). The samples dried under vacuum at $453 \mathrm{~K}$ for $24 \mathrm{~h}$ were contained in a silica tube in a glove bag under an Ar atmosphere. Then, a balloon was set to the open end of the tube with a paraffin film to maintain the atmosphere. The tube was inserted to a silica chamber (i.d. $127 \mathrm{~mm}$, height $403 \mathrm{~mm}$ ) in an electric furnace maintained at $1123 \mathrm{~K}$, and was left for a given period of time. The tube was pulled out in one minute, and then cooled at room temperature. The Zn sample was weighed after water washing and drying. In the case that the separation of Zn sample from the silica tube was difficult, its weight was calculated from the values before and after leaching treatment with $1 \mathrm{M} \mathrm{HCl}$ solutions. The $\mathrm{Zn}$ content in the molten salt was analyzed by inductively coupled plasma atomic emission spectrometry (ICP-AES: Thermo Scientific, iCAP 6200 Duo) for a solution prepared by dissolving $0.1 \mathrm{~g}$ of recovered $\mathrm{CaCl}_{2}$ into $\mathrm{HNO}_{3}$ solution.

\section{Electrochemical behavior}

Figure 3 shows the schematic illustration of the electrochemical apparatus. $350 \mathrm{~g}$ of $\mathrm{CaCl}_{2}$ was charged in an alumina crucible (Nikkato Corp., SSA-S grade, o.d. $87 \mathrm{~mm}$, i.d. $80 \mathrm{~mm}$, height $129 \mathrm{~mm}$ ) and dried under vacuum at $453 \mathrm{~K}$ and $773 \mathrm{~K}$ for $24 \mathrm{~h}$, respectively. All the electrochemical experiments were carried out in a dry $\mathrm{Ar}$ atmosphere at $1123 \mathrm{~K}$. Electrochemical behavior was investigated by cyclic voltammetry and potentiostatic electrolysis using a newly designed liquid Zn electrode. Figure 4 shows a photograph and a schematic illustration of a liquid $\mathrm{Zn}$ electrode. Zn grains (Kojundo Chemical Laboratory Co., Ltd., 99.9999\%, grains, 3 5 mm, 1.3 g) were set at the bottom of an alumina tube (Nikkato Corp., SSA-S grade, o.d. $13 \mathrm{~mm}$, i.d. $9 \mathrm{~mm}$ ) with an open window with a size of $10 \mathrm{~mm} \times 20 \mathrm{~mm}$ at the side. A Mo wire (Nilaco Corp., dia. $1.0 \mathrm{~mm}$, 99.95\%) thread into an alumina insulating tube (Nikkato Corp., SSA-S grade, o.d. 2.0 
mm, i.d. $1.0 \mathrm{~mm}$ ) was used to an electric lead. Purified $\mathrm{SiO}_{2}$ grains (Taiheiyo Cement Corp., dia. $<0.1 \mathrm{~mm}, 0.30 \mathrm{~g}$ ) was set above the $\mathrm{Zn}$ grains. The densities of liquid $\mathrm{Zn}$, solid $\mathrm{SiO}_{2}$ and molten $\mathrm{CaCl}_{2}$ are $5.9 \mathrm{~g} \mathrm{~cm}^{-3}$ [60], $2.2 \mathrm{~g} \mathrm{~cm}^{-3}, 2.05 \mathrm{~g} \mathrm{~cm}^{-3}$ [61] at $1123 \mathrm{~K}$, respectively. The counter electrode was a graphite rod (Tokai Carbon Co., Ltd., dia. 5.0 $\mathrm{mm})$. An $\mathrm{Ag}^{+} / \mathrm{Ag}$ electrode was used as a reference electrode [17]. In the cyclic voltammetry, an in-situ IR compensation using the electrochemical measurement system was carried out with a compensation ratio of $95 \%$ which was the highest value in the range without bringing potential instability. The sample after potentiostatic electrolysis was recovered from the cell in one minute, followed by cooling at room temperature. The samples contained in the alumina tube were cut into halves, and were polished with emery paper (\#240, 400, 600, 1000, and 2000) and buffing compound (Micro Polish II, $0.3 \mu \mathrm{m}$, Buehler). The analysis was carried with scanning electron microscopy, (SEM; Keyence Corp., VE-8800) and energy-dispersive X-ray spectroscopy (EDX; AMETEK, EDAX Genesis APEX2).



Figure 3. A schematic drawing of the electrolysis cell. (a) $\mathrm{Ag}^{+} / \mathrm{Ag}$ reference electrode, (b) graphite counter electrode, (c) liquid $\mathrm{Zn}$ electrode with $\mathrm{SiO}_{2}$ granules, (d) $\mathrm{Ca}^{2+} / \mathrm{Ca}$ dynamic reference electrode on a Mo wire, (e) thermocouple, (f) molten $\mathrm{CaCl}_{2}$, and (g) alumina crucible. 
(a)

(b)

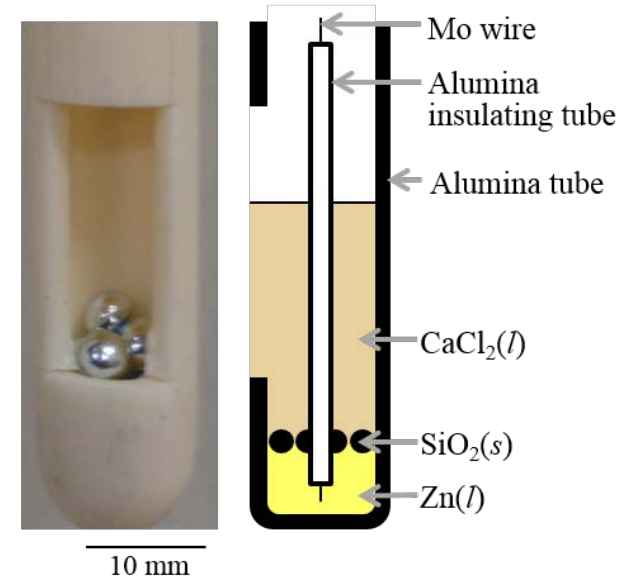

Figure 4. (a) A photograph and (b) schematic illustration of the Zn electrode. Alloying reaction between solid $\mathrm{Si}$ and liquid $\mathrm{Zn}$

$330 \mathrm{~g}$ or $660 \mathrm{~g}$ of Zn granules (Wako Pure Chemical Industries, Ltd., grains) were charged into $210 \mathrm{~g}$ of molten $\mathrm{CaCl}_{2}$ to prepare $\mathrm{Zn}$ pool in a graphite crucible (Toyo Tanso Co., Ltd., IG-110 grade, o.d. $90 \mathrm{~mm}$, i.d. $80 \mathrm{~mm}$, height $120 \mathrm{~mm}$ ) in a dry Ar atmosphere at $1123 \mathrm{~K}$. Single crystal Si plates (SUMCO Corp., $6 \mathrm{~mm} \times 35 \mathrm{~mm}$, thickness $0.5 \mathrm{~mm}$, ntype, (100) plane, resistivity 1-10 $\Omega \mathrm{cm}$ ) or Si prismatic rods (Furuuchi Chemical Corp., $4 \mathrm{~mm} \times 4 \mathrm{~mm}$, height $30 \mathrm{~mm}$ ) attached to Ni wire (Ryoko Sangyo Co., Ltd. >99\%, dia. 1.0 $\mathrm{mm}$ ) and mullite tubes (Nikkato Corp., HB-grade, o.d. $6 \mathrm{~mm}$, i.d. $4 \mathrm{~mm}$, length $500 \mathrm{~mm}$ ) were immersed into the Zn pool for 2-60 seconds. Si round rods (Furuuchi Chemical Corp., dia. $6 \mathrm{~mm}$, length $50 \mathrm{~mm}$ ) fixed to a stainless steel tube (SUS304, o.d. $12.0 \mathrm{~mm}$, i.d. $8.0 \mathrm{~mm}$, length $500 \mathrm{~mm}$ ) with a ceramic bond was also used for the measurements. For some experiments, Si lumps were added to liquid $\mathrm{Zn}$ pool to prepare $\mathrm{Si}-\mathrm{Zn}$ alloys. Si samples were immersed to the $\mathrm{Zn}$ pool or $\mathrm{Si}-\mathrm{Zn}$ pool for a fixed duration time, and then pulled out to be cooled at room temperature. After washing of the adhered salt with water, the thickness or diameter of the Si specimens before and after the immersion was measured by a micrometer.

\section{Results and discussion}

\section{$\underline{\text { Evaporation of Zn }}$}

Prior to the electrochemical experiments, to eliminate the concern that metallic $\mathrm{Zn}$ is not utilized as a liquid electrode because of the immediate evaporation at the temperature close to its boiling point; the vapor pressure of $\mathrm{Zn}$ at the electrolysis temperature of 1123 $\mathrm{K}$ is $0.54 \mathrm{~atm}$ [50]. Thus, evaporation behavior of $\mathrm{Zn}$ immersed in molten $\mathrm{CaCl}_{2}$ was measured.

Figure 5 shows the photographs before and after the evaporation experiments at 1123 $\mathrm{K}$ for $6 \mathrm{~h}$. When only Zn metal was set at the bottom of the tube in Ar atmosphere, a considerable amount of Zn deposits was observed at the upper part of tube inside where the temperature was lower (Fig. 5(a-2)). These deposits result from the evaporation and transport from the liquid $\mathrm{Zn}$ in the gas phase. On the other hand, in the presence of molten $\mathrm{CaCl}_{2}$ layer of 5.4-5.6 g, solidified $\mathrm{CaCl}_{2}$ and $\mathrm{Zn}$ layers were observed and no 
deposit was formed at the upper part as shown in Fig. 5(b-2). The position order of these layers is determined by the density, and the layer thickness is as large as the calculated values ( $\mathrm{Zn} ; 10 \mathrm{~mm}, \mathrm{CaCl}_{2} ; 31 \mathrm{~mm}$ ). The weight loss of $\mathrm{Zn}$ metal in the experiments with/without the presence of molten $\mathrm{CaCl}_{2}$ over liquid $\mathrm{Zn}$ is summarized in Table 2 and plotted in Fig. 6 (a) with reaction time. The graph obviously shows that the evaporation is significantly suppressed by the presence of molten salt above liquid Zn metal. In both cases, the weight of Zn metal almost linearly decreases with time. The evaporation rate determined by the slope of the plot is $1.90 \times 10^{-1} \mathrm{~g} \mathrm{~cm}^{-2} \mathrm{~h}^{-1}$ when only $\mathrm{Zn}$ metal was used. The rate greatly decreased to $4.45 \times 10^{-3} \mathrm{~g} \mathrm{~cm}^{-2} \mathrm{~h}^{-1}$ (0.023 times) with the presence of molten salt, which corresponds to the evaporation rate of $0.18 \mathrm{~mm}^{-1}{ }^{-1}$. Thus, the evaporation of $\mathrm{Zn}$ metal covered with molten $\mathrm{CaCl}_{2}$ is found to be negligibly small when it is used as a cathode in the electrolysis process in spite of the high vapor pressure of $\mathrm{Zn}$.

Figure 6(b) compares the evaporation behavior at different thickness of molten $\mathrm{CaCl}_{2}$ layer. The evaporation rates at $31 \mathrm{~mm}$ and $47 \mathrm{~mm}$ thickness are $4.45 \times 10^{-3} \mathrm{~g} \mathrm{~cm}^{-2} \mathrm{~h}^{-1}$ and $2.75 \times 10^{-3} \mathrm{~g} \mathrm{~cm}^{-2} \mathrm{~h}^{-1}$, respectively. Since the concentration of $\mathrm{Zn}$ in molten $\mathrm{CaCl}_{2}$ after the reaction for 24 hours at $31 \mathrm{~mm}$ thickness was $0.91 \mathrm{wt} \%$ determined by ICP-AES, $\mathrm{Zn}$ metal is thought to firstly dissolve to the molten salt and then evaporate at the interface between the gas and molten salt after the transport in the melt. As shown in Fig. $6(\mathrm{~b})$, the rate of weight loss varies inversely as layer thickness of $\mathrm{CaCl}_{2}$. Thus, the diffusion in the molten salt is likely the rate determining step.

Table 2 Weight of Zn samples after evaporation experiments at $1123 \mathrm{~K}$.

\begin{tabular}{|c|c|c|c|c|c|c|}
\hline \multirow[b]{2}{*}{$\begin{array}{l}\text { Time, } \\
t / \mathrm{h}\end{array}$} & \multirow{2}{*}{$\begin{array}{l}\text { Thickness of } \\
\mathrm{CaCl}_{2} \text { layer, } \\
l_{\mathrm{CaCl}_{2}} / \mathrm{mm}\end{array}$} & \multirow[b]{2}{*}{$\begin{array}{c}\text { Surface area, } \\
A / \mathrm{cm}^{2}\end{array}$} & \multicolumn{4}{|c|}{ Weight of Zn } \\
\hline & & & $\begin{array}{l}\text { Before, } \\
W_{\text {bef }} / g\end{array}$ & $\begin{array}{l}\text { After, } \\
W_{\text {aft }} / g\end{array}$ & $\begin{array}{l}\text { Loss }^{\mathrm{a}}, \\
W_{\text {loss }} / \mathrm{g}\end{array}$ & $\begin{array}{c}\text { Loss }{ }^{\mathrm{b}}, \\
w_{\text {loss }} / \mathrm{g} \mathrm{cm}^{-2}\end{array}$ \\
\hline 0.25 & 0 & \multirow{8}{*}{0.866} & 5.5322 & 5.2184 & $3.14 \times 10^{-1}$ & 0.362 \\
\hline 0.25 & 31 & & 5.5119 & 5.5026 & $9.30 \times 10^{-3}$ & 0.0107 \\
\hline 6 & 0 & & 5.4502 & 4.3979 & 1.05 & 1.22 \\
\hline 6 & 31 & & 5.6016 & 5.5730 & $2.86 \times 10^{-2}$ & 0.0330 \\
\hline 6 & 47 & & 5.4916 & 5.4672 & $2.44 \times 10^{-2}$ & 0.0282 \\
\hline 24 & 0 & & 5.5781 & 1.6440 & 3.93 & 4.54 \\
\hline 24 & 31 & & 5.5310 & 5.4401 & $9.09 \times 10^{-2}$ & 0.105 \\
\hline 24 & 47 & & 5.4688 & 5.4141 & $5.47 \times 10^{-2}$ & 0.0632 \\
\hline
\end{tabular}




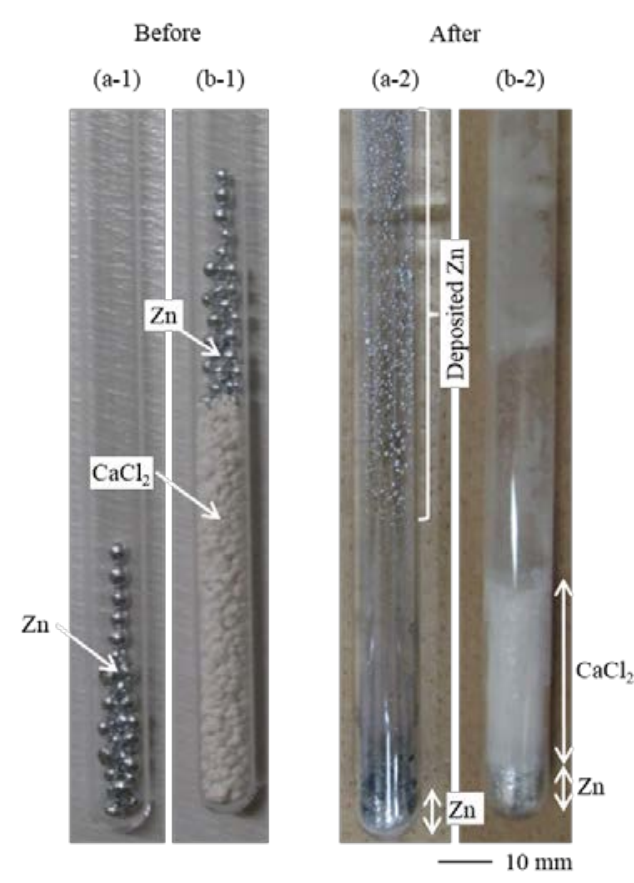

Figure 5 Photographs of the samples before ((a-1) and (b-1)) and after ((a-2) and (b-2)) the evaporation experiments. The evaporation experiments were conducted without ( $(\mathrm{a}-1)$ and (b-1)) and with ((a-2) and (b-2)) the immersion into molten $\mathrm{CaCl}_{2}$ at $1123 \mathrm{~K}$ for $6 \mathrm{~h}$.

(a)

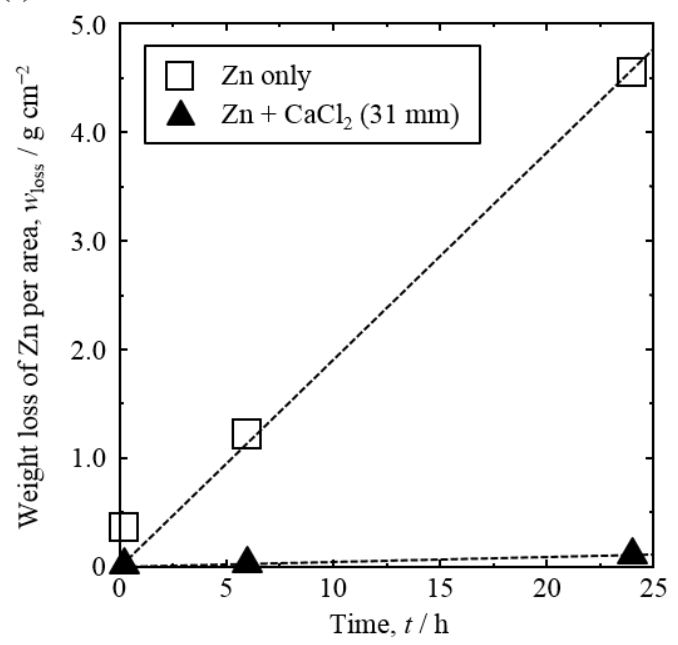

(b)

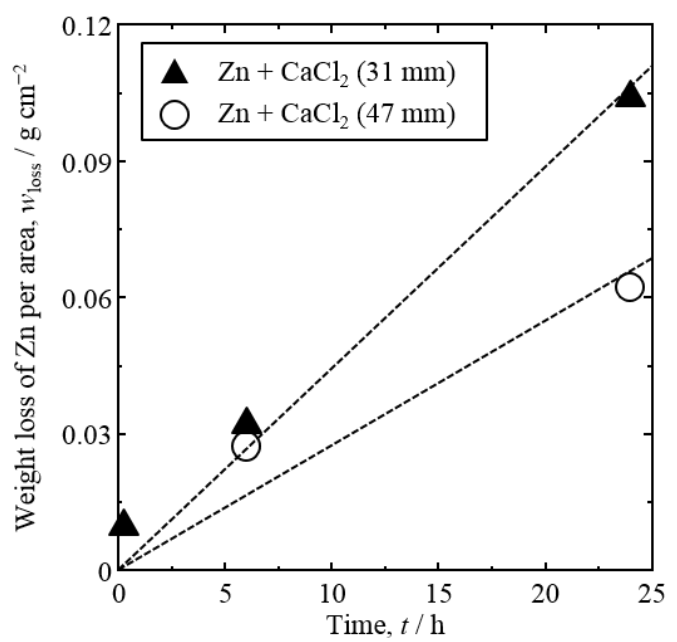

Figure 6. Weight loss of $\mathrm{Zn}$ per area at $1123 \mathrm{~K}$. (a) Plots are compared against the immersion of $\mathrm{Zn}$ sample in molten $\mathrm{CaCl}_{2}$. (b) Plots are compared against thickness of $\mathrm{CaCl}_{2}$ layer for $31 \mathrm{~mm}$ and $47 \mathrm{~mm}$.

\section{Electrochemical behavior}

Figure 7 shows the cyclic voltammograms for a liquid $\mathrm{Zn}$ electrode with/without $\mathrm{SiO}_{2}$ granules. The solid curve for $\mathrm{Zn}$ metal only indicates the negative current around $50 \mathrm{~mA}$ $\mathrm{cm}^{-2}$ from the rest potential $(1.48 \mathrm{~V})$ and the sharp current increase at $0.9 \mathrm{~V}$. Since $\mathrm{Ca}$ and $\mathrm{Zn}$ forms a liquid phase over the all composition range at $1123 \mathrm{~K}$ [62], this current is supposed to be due to the formation of liquid $\mathrm{Ca}-\mathrm{Zn}$ alloy. To confirm the reaction, the $\mathrm{Zn}$ electrode was galvanostatically electrolyzed at $-1.06 \mathrm{~A} \mathrm{~cm}^{-2}$ for $30 \mathrm{~min}$. The open- 
circuit potential immediately after the electrolysis was $0.35 \mathrm{~V}$. When the sample was analyzed by EDX, the composition of the surface zone was determined to be 90 at\%Zn10 at\%Ca. This value agrees with the calculated value from the reported activity coefficient of $\mathrm{Ca}$ in liquid $\mathrm{Ca}-\mathrm{Zn}$ alloy at $1073 \mathrm{~K}$ under Henry's law [63]. Incidentally, Ca content was lower than the detection limit of EDX in the samples obtained by potentiostatic electrolysis at $0.90 \mathrm{~V}$, which is explained by smaller quantity of electricity compared to the galvanostatic electrolysis. From the above results, the reduction current observed at more negative than $0.9 \mathrm{~V}$ is attributed to the formation of liquid $\mathrm{Ca}-\mathrm{Zn}$ alloys.

$$
\mathrm{Zn}(l)+y \mathrm{Ca}^{2+}+2 y \mathrm{e}^{-} \rightarrow \mathrm{ZnCa}_{y}(l)
$$

The broken curve in Fig. 7 shows the voltammogram for the Zn electrode after the addition of $\mathrm{SiO}_{2}$. While the rest potential is almost identical before the addition of $\mathrm{SiO}_{2}$, the larger cathodic currents of $100 \mathrm{~mA} \mathrm{~cm}{ }^{-2}$ are observed during the scan to the negative direction. Thus, the formation of $\mathrm{Si}-\mathrm{Zn}$ alloy is expected between $0.9 \mathrm{~V}$ and $1.45 \mathrm{~V}$. Here, the onset potential of $\mathrm{SiO}_{2}$ reduction on the liquid $\mathrm{Zn}$ cathode $(1.45 \mathrm{~V})$ is more positive compared with that on a Mo electrode (1.25 V) [16], which is explained by the lower activity of Si in the Zn-Si alloy.

$$
\mathrm{SiO}_{2}(s)+\mathrm{Zn}(l)+4 \mathrm{e}^{-} \rightarrow \mathrm{Si}-\mathrm{Zn}(l)+2 \mathrm{O}^{2-}
$$

On the basis of the voltammertic results, potentiostatic electrolysis was conducted for a liquid $\mathrm{Zn}$ electrode after adding $\mathrm{SiO}_{2}$ granules with a diameter of $0.1 \mathrm{~mm}$ at $0.90 \mathrm{~V}$ for $5.5 \mathrm{~h}$ in molten $\mathrm{CaCl}_{2}$ at $1123 \mathrm{~K}$. The sample was observed after cross-sectioning in the vertical direction. Figure 8(a) and (b) show cross-sectional optical and SEM images of the sample after the electrolysis, respectively. The precipitated grains are observed only at the upper part of the Zn electrode. As shown in the magnified SEM image in Fig. 8(c) and EDX analysis, Si particles with a diameter of 2 30 $\mu \mathrm{m}$ are deposited in $\mathrm{Zn}$ matrix. According to the Si-Zn phase diagram [52], solubility of Si in liquid Zn metal is 6.0 at\% at $1123 \mathrm{~K}$ and it becomes negligibly small in solid $\mathrm{Zn}$ at room temperature. Thus, it is reasonable to conclude that $\mathrm{SiO}_{2}$ was electrochemically reduced to form liquid $\mathrm{Si}-\mathrm{Zn}$ alloy (reaction (5)), and that Si particles were precipitated during the cooling process. The Si precipitated particles were observed only at the upper part because they floated and aggregated in the liquid phase due to the smaller density. 




Figure 7. Cyclic voltammograms for liquid $\mathrm{Zn}$ electrodes in molten $\mathrm{CaCl}_{2}$ at $1123 \mathrm{~K}$. Scan rate: $0.2 \mathrm{~V} \mathrm{~s}^{-1}$.

(a)

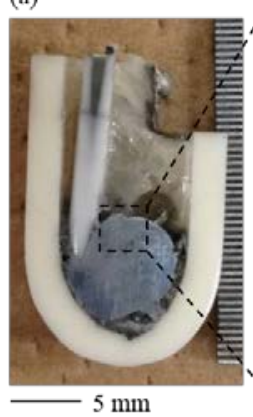

(b)



(c)

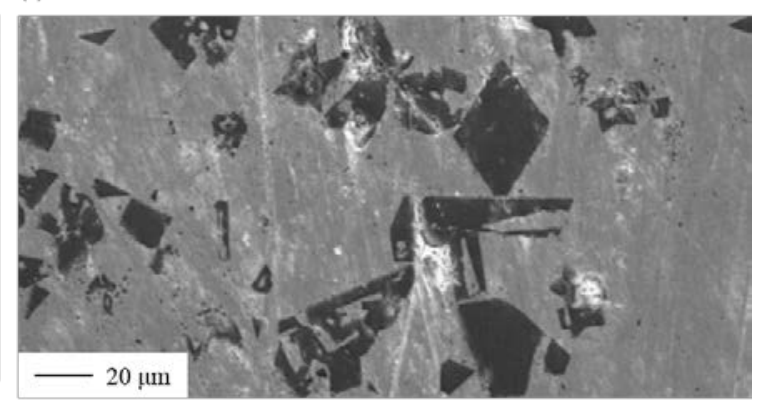

Figure 8. (a) A photograph and (b)(c) cross-sectional SEM images of the sample obtained by potentiostatic electrolysis of liquid $\mathrm{Zn}$ electrode with $\mathrm{SiO}_{2}$ granules at $0.90 \mathrm{~V}$ for 60 min in molten $\mathrm{CaCl}_{2}$ at $1123 \mathrm{~K}$.

\section{Alloying reaction between solid Si and liquid $\mathrm{Zn}$}

Figure 9 shows the photographs before and after the alloying experiments at $1123 \mathrm{~K}$ for different immersion time. After the experiments, Zn was not found on the surface of the recovered Si plate by both direct observation and EDX analysis. The liquid alloy formed at high temperature was probably removed during pulling out through the molten $\mathrm{CaCl}_{2}$ layer. From the photos in Fig. 9, the decrease of plate thickness by the dissolution of $\mathrm{Si}$ is clearly observed in direct observation even after the immersion for 2 seconds. For the Si plate reacted for 60 seconds, the whole immersed portion was completely disappeared. Since the alloying reaction proceeds at both the sides of Si plate, the reduced thickness was evaluated as a value for one side, which is listed in Table 3. As shown in Fig. 10, the thickness of the plate linearly decreases with the immersion time, and the alloying rate is determined to be $4.56 \mu \mathrm{m} \mathrm{s}^{-1}$ from the slope of the plots. 
The similar measurements were conducted for $\mathrm{Si}-\mathrm{Zn}$ alloy pools with different $\mathrm{Si}$ concentrations, and the results are summarized in Table 3 and Fig. 10. The decrease of alloy formation rate is observed with the Si concentration in liquid alloy. Here, the alloy formation rate $\left(v_{\text {alloy }}\right)$ is plotted in Fig. 11 against the Si concentration $\left(c_{\mathrm{Si}}\right)$ in the alloy. Linear relationship between $v_{\text {alloy }}$ and $c_{\mathrm{Si}}$ is clearly observed.

$$
v_{\text {alloy }}=-0.747 c_{\mathrm{Si}}+4.49=0.747^{*}\left(6.0-c_{\mathrm{Si}}\right)
$$

The extrapolation indicates that alloy formation rate becomes zero at 6.0 at\% $\mathrm{Si}$, which agrees with the solubility in liquid $\mathrm{Si}-\mathrm{Zn}$ alloy [52]. This fact suggests that the alloying reaction is controlled by the diffusion of $\mathrm{Si}$ atoms in the diffusion layer between solid $\mathrm{Si}$ and liquid $\mathrm{Zn}$. The diffusion of Si in liquid $\mathrm{Zn}$ is expected to be fast in the order of $10^{-4}$ $\mathrm{cm}^{2} \mathrm{~s}^{-1}$ from the reported diffusion coefficients, $D$, of $\mathrm{Fe}\left(1-5 \times 10^{-4} \mathrm{~cm}^{2} \mathrm{~s}^{-1}\right.$ [64]) and $\mathrm{Al}$ $\left(1.1 \times 10^{-4} \mathrm{~cm}^{2} \mathrm{~s}^{-1}\right.$ [65]) at $1123 \mathrm{~K}$. From the alloy formation rate of $4.56 \mu \mathrm{m} \mathrm{s}^{-1}$ and the estimated diffusion coefficient of $1 \times 10^{-4} \mathrm{~cm}^{2} \mathrm{~s}^{-1}$, the diffusion layer thickness, $l$, is calculated to be $145 \mu \mathrm{m}$ at the reaction time, $t^{\prime}$, at 1.05 seconds by using the relation of $l=\sqrt{2 D t}$. Thus, the plots in Fig. 10 does not show a parabolic relation but a linear.

In order to estimate the rate-determining step of electrochemical reduction of $\mathrm{SiO}_{2}$ using liquid $\mathrm{Zn}$ electrode, the alloying rate is compared with the reaction rate in other steps involved in the reaction. According to our previous studies, the reduction rates are estimated from the results at the reaction time of $300 \mathrm{~s}$ in molten $\mathrm{CaCl}_{2}$ at $1123 \mathrm{~K}$ as 2.1 $\mu \mathrm{m} \mathrm{s}^{-1}$ [18] and $0.27 \mu \mathrm{m} \mathrm{s}^{-1}$ [16] for the surface and inner directions of solid $\mathrm{SiO}_{2}$, respectively. Furthermore, the reaction for the inner direction becomes slower with the electrolysis time because the diffusion length for the $\mathrm{O}^{2-}$ ions in the porous Si layer becomes larger. Thus, the larger alloy formation rate than the reduction rates suggests the fast removal of the porous Si layer formed at the outermost surface of the $\mathrm{SiO}_{2}$. This behavior is similar to the removal of $\mathrm{Nd}-\mathrm{Fe}$ liquid alloy from the surface of iron cathode in the rare earth electrometallurgy [66]. The removal of the surface layer retarding the diffusion of $\mathrm{O}^{2-}$ ions would to lead to the continuation of the fast reaction which was confirmed to be equivalent to $0.7 \mathrm{~A} \mathrm{~cm}^{-2}$ in the Hall-Héroult process using molten salt electrolysis [20,21].

Table 3. Thickness of Si plate or diameter of Si rod and alloy formation rate into Zn pool at each Si concentration at $1123 \mathrm{~K}$.

\begin{tabular}{|c|c|c|c|c|c|}
\hline \multirow{2}{*}{$\begin{array}{l}\text { Si conc. in } \\
\text { Zn pool, } \\
c_{\mathrm{si}} / \text { at } \%\end{array}$} & \multirow{2}{*}{$\begin{array}{l}\text { Immersion } \\
\text { time, } \\
t_{\mathrm{im}} / \mathrm{s}\end{array}$} & \multicolumn{3}{|c|}{ Thickness of Si plate } & \multirow{2}{*}{$\begin{array}{c}\text { Alloy } \\
\text { formation rate }{ }^{\mathrm{b}} \text {, } \\
v_{\text {alloy }} / \mu \mathrm{m} \mathrm{s}^{-1}\end{array}$} \\
\hline & & $\begin{array}{c}\text { Before } \\
\text { immersion, } \\
L_{\text {bef }} / \mu \mathrm{m}\end{array}$ & $\begin{array}{c}\text { After } \\
\text { immersion, } \\
L_{\text {aft }} / \mu \mathrm{m}\end{array}$ & $\begin{array}{l}\text { Reduced value } \\
\text { for one side }{ }^{\mathrm{a}} \text {, } \\
L_{\text {reduced }} / \mu \mathrm{m}\end{array}$ & \\
\hline \multirow{4}{*}{0} & 0 & - & - & 0 & \multirow{4}{*}{$4.56^{c}$} \\
\hline & 2 & 534 & 494 & 20 & \\
\hline & 20 & 531 & 378 & 77 & \\
\hline & 40 & 530 & 158 & 186 & \\
\hline
\end{tabular}




\begin{tabular}{rrrrrl}
\cline { 2 - 5 } & \multicolumn{1}{c}{60} & 526 & 0 & $(263)$ & \\
\hline 1.10 & 120 & 4021 & 3171 & 425 & 3.54 \\
\hline 2.40 & 120 & 5992 & 5332 & 330 & 2.75 \\
\hline 4.87 & 60 & 530 & 428 & 51 & 0.85 \\
\hline
\end{tabular}
a: $L_{\text {reduced }}=\frac{L_{\text {baf }}-L_{\text {aft }}}{2}$
b: $v_{\text {alloy }}=\frac{L_{\text {reduced }}}{t_{\text {im }}}$
c: Calculated from the slope of the plots in Fig. 10.

(a)

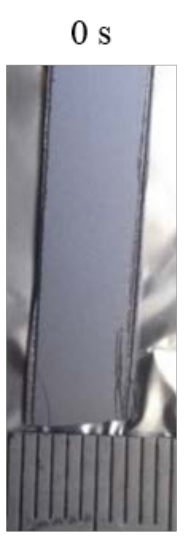

(b)

$$
2 \mathrm{~s}
$$

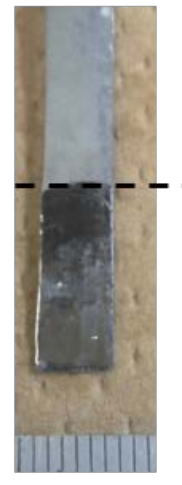

(c)

$$
20 \mathrm{~s}
$$

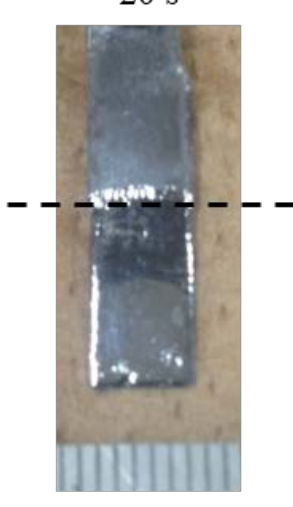

(d)


ca. $5 \mathrm{~mm}$

Figure 9. Photographs of the Si plates (a) before and after the immersion into Zn pool at $1123 \mathrm{~K}$ for (b) $2 \mathrm{~s}$, (c) $20 \mathrm{~s}$, (d) $40 \mathrm{~s}$, and (e) $60 \mathrm{~s}$. 


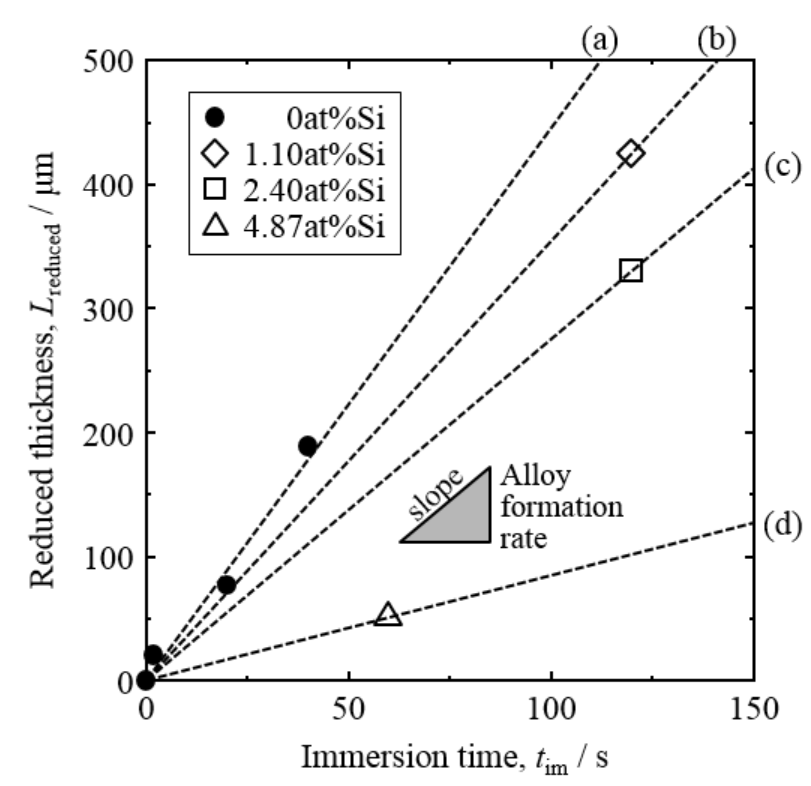

Figure 10. Decreased thickness of Si plate and rod after immersion at $1123 \mathrm{~K}$. Si concentration in Zn pool was (a) 0 at\%, (b) 1.10 at\%, (c) 2.40 at\%, and (d) 4.87 at\%.

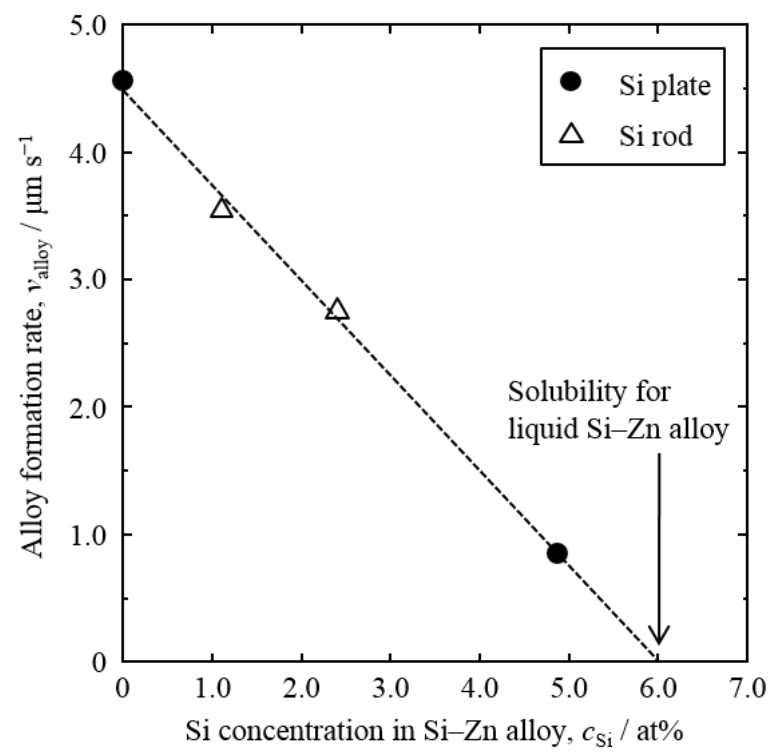

Figure 11. Dependence of alloy formation rate on Si concentration in liquid Si-Zn alloy at $1123 \mathrm{~K}$.

\section{Conclusions}

The electrolytic production process of SOG-Si utilizing liquid Si-Zn alloy in molten $\mathrm{CaCl}_{2}$ was proposed. The presence of molten salt above a liquid $\mathrm{Zn}$ layer significantly suppressed the evaporation of $\mathrm{Zn}$. The evaporation rate at $1123 \mathrm{~K}$ was $0.18 \mathrm{~mm}$ day $^{-1}$, which is enough small to use as a liquid $\mathrm{Zn}$ cathode. The reduction of $\mathrm{SiO}_{2}$ granules on the $\mathrm{Zn}$ cathode to form liquid $\mathrm{Si}-\mathrm{Zn}$ alloy was suggested to proceed from $1.45 \mathrm{~V}$ vs. $\mathrm{Ca}^{2+} / \mathrm{Ca}$ and confirmed at $0.9 \mathrm{~V}$. The alloy formation rate of solid $\mathrm{Si}$ and liquid 
Zn was measured to be $4.56 \mu \mathrm{m} \mathrm{s}^{-1}$ at $1123 \mathrm{~K}$, which indicates the potential of fast reduction of $\mathrm{SiO}_{2}$.

\section{Acknowledgments}

This study was partly supported by Core Research for Evolutionary Science and Technology (CREST) from Japan Science and Technology Agency (JST), Grants-in-Aid for Scientific Research A from the Japan Society for the Promotion of Science (JSPS), The Japan Prize Foundation, and Kato Foundation for Promotion of Science. The purified $\mathrm{SiO}_{2}$ granules were supplied by Taiheiyo Cement Corporation.

\section{References}

1. Photovoltaic Market 2014, RTS Corp., Tokyo, Japan, 2014. [in Japanese]

2. Rare Metal News, on Aug. 24, 2014, Arumu Publishing Co., Tokyo, Japan. [in Japanese]

3. H. Schweickert, K. Reuschel, and H. Gutsche: U.S. Patent, US3,011,877, 1961.

4. H. Gutsche: U.S. Patent, US3,042,494, 1962.

5. F. Bischoff: U.S. Patent, US3,146,123, 1964.

6. K. Reuschel and A. Kersting: U.S. Patent, US3,200,009, 1965.

7. K. Yasuda and T. H. Okabe: JOM, 2010, vol. 62, pp. 94-101.

8. K. Yasuda, K. Morita, and T. H. Okabe: Energy Technology, 2014, vol. 2, pp. 141-54.

9. G. Bye and B. Ceccaroli: Sol. Energy Mater. Sol. Cells, 2014, vol. 130, pp. 63446.

10. T. Nohira, K. Yasuda, and Y. Ito: Nat. Mater., 2003, vol. 2, pp. 397-401.

11. K. Yasuda, T. Nohira, K. Amezawa, Y. H. Ogata, and Y. Ito: J. Electrochem. Soc., 2005, vol. 152, pp. D69-74.

12. T. Nohira, Yoyuen Oyobi Koon Kagaku, 2011, vol. 54, pp. 95-103. [in Japanese]

13. K. Yasuda, T. Nohira, R. Hagiwara, and Y. H. Ogata: Electrochim. Acta, 2007, vol. 53, pp. 106-10.

14. K. Yasuda, T. Nohira, K. Kobayashi, N. Kani, T. Tsuda, and R. Hagiwara: Energy Technology, 2013, vol. 1, pp. 245-52.

15. T. Toba, K. Yasuda, T. Nohira, X. Yang, R. Hagiwara, K. Ichitsubo, K. Masuda, and T. Homma: Electrochemistry, 2013, vol. 81, pp. 559-65.

16. K. Yasuda, T. Nohira, and Y. Ito: J. Phys. Chem. Solids, 2005, vol. 66, pp. 44347.

17. K. Yasuda, T. Nohira, R. Hagiwara, and Y. H. Ogata: J. Electrochem. Soc., 2007, vol. 154, pp. E95-101.

18. K. Yasuda, T. Nohira, K. Takahashi, R. Hagiwara, and Y. H. Ogata: J. Electrochem. Soc., 2005, vol. 152, pp. D232-37.

19. Y. Nishimura, T. Nohira, K. Yasuda, Y. Fukunaka, and R. Hagiwara: Trans. Mater. Res. Soc. Jpn., 2010, vol. 35, pp. 47-49.

20. X. Yang, K. Yasuda, T. Nohira, R. Hagiwara, and T. Homma: Metall. Mater. Trans. B, 2014, vol. 45B, pp. 1337-44.

21. X. Yang, K. Yasuda, T. Nohira, R. Hagiwara, and T. Homma: J. Electrochem. Soc., 2014, vol. 161, pp. D3116-19. 
22. X. Yang, K. Yasuda, T. Nohira, R. Hagiwara, and T. Homma: Metall. Mater. Trans. B, 2016, vol. 47B, pp. 788-97.

23. X. Jin, P. Gao, D. Wang, X. Hu, and G. Z. Chen: Angew. Chem., 2004, vol. 116, pp. 751-54.

24. P. C. Pistorius and D. J. Fray: J. S. Afr. Inst. Min. Metall., 2006, vol. 106, pp. 3141.

25. W. Xiao, X. Jin, Y. Deng, D. Wang, X. Hu, and G. Z. Chen: ChemPhysChem, 2006, vol. 7, pp. 1750-58.

26. S. Lee, J. Hur, and C. Seo: J. Ind. Eng. Chem., 2008, vol. 14, pp. 651-54.

27. W. Xiao, X. Jin, Y. Deng, D. Wang, X. Hu, and G. Z. Chen: J. Electroanal. Chem., 2010, vol. 639, pp. 130-40.

28. E. Juzeliunas, A. Cox, and D. J. Fray: Electrochem. Comm., 2010, vol. 12, pp. 1270-74.

29. T. Oishi, M. Watanabe, K. Koyama, M. Tanaka, and K. Saegusa: J. Electrochem. Soc., 2011, vol. 158, pp. E93-99

30. E. Ergül, İ. Karakaya, and M. Erdoğan: J. Alloy. Compd., 2011, vol. 509, pp. 899903.

31. W. Xiao, X. Wang, H. Yin, H. Zhu, X. Mao, and D. Wang: RSC Advances, 2012, vol. 2, pp. 7588-93.

32. S. K. Cho, F. F. Fan, and A. J. Bard: Electrochim. Acta, 2012, vol. 65, pp. 57-63.

33. S. K. Cho, F. F. Fan, and A. J. Bard: Angew. Chem., 2012, vol. 124, pp. 12912-16.

34. W. Xiao, X. Jin, and G. Z. Chen: J. Mater. Chem. A., 2013, vol. 1, pp. 10243-50.

35. T. Yoshikawa and K. Morita: Sci. Technol. Adv. Mater., 2003, vol. 4, pp. 531-37.

36. T. Yoshikawa and K. Morita: CAMP-ISIJ, 2004, vol. 17, p. 875.

37. T. Yoshikawa and K. Morita: Proc. EPD Congress 2005, TMS, Warrendale, pp. 549-58, 2005.

38. T. Yoshikawa and K. Morita: J. Cryst. Growth, 2009, vol. 311, pp. 776-79.

39. T. Yoshikawa and K. Morita: JOM, 2012, vol. 64, pp. 946-51

40. J. M. Juneja and T. K. Mukherjee: Hydrometallurgy, 1986, vol. 16, pp. 69-75.

41. A. M. Mitrašinović and T. A. Utigard: Silicon, 2009, vol. 1, pp. 239-48.

42. X. Ma, T. Yoshikawa, and K. Morita: J. Alloy. Compd., 2012, vol. 529, pp. 12-16.

43. X. Ma, T. Yoshikawa, and K. Morita: Sep. Purif. Technol., 2014, vol. 125, pp. 264-68.

44. L. Hu, Z. Wang, X. Gong, Z. Guo, and H. Zhang: Metall. Mater. Trans. B, 2013, vol. 44B, pp. 828-36.

45. S. Esfahani and M. Barati: Metals Mater. Int., 2011, vol. 17, pp. 823-29.

46. S. Esfahani and M. Barati: Metals Mater. Int., 2011, vol. 17, pp. 1009-15.

47. L. T. Khajavi, K. Morita, T. Yoshikawa, and M. Barati: Metall. Mater. Trans. B, 2015, vol. 46B, pp. 615-20.

48. Z. Yin, A. Oliazadeh, S. Esfahani, M. Johnston, and M. Barati: Can. Metall. Q., 2011, vol. 50, pp. 166-72.

49. H. Morito, T. Karahashi, M. Uchikoshi, M. Isshiki, and H. Yamane: Silicon, 2012, vol. 4, pp. 121-25.

50. M. W. Jr. Chase, C. A. Davies, J. R. Jr. Downey, D. J. Frurip, R. A. McDonald and A. N. Syverud: NIST-JANAF Thermochemical Tables, 4th ed., J. Phys. Chem. Ref. Data, Monograph No. 9, American Chemical Society and the American Institute of Physics for the National Institute of Standards and Technology, New York, USA, 1998. 
51. I. Barin, O. Knacke, and O. Kubaschewski: Thermochemical Properties of Inorganic Substances, Supplement, Springer-Verlag, Berlin, Germany, 1977.

52. R.W. Olesinski and G. J. Abbaschian: J. Phase Equilib., 1985, vol. 6, pp. 545-48.

53. R.W. Olesinski and G. J. Abbaschian: J. Phase Equilib., 1984, vol. 5, pp. 273-76.

54. R.W. Olesinski and G. J. Abbaschian: J. Phase Equilib., 1984, vol. 5, pp. 271-73.

55. J. L. Murray and A. J. McAlister: Bulletin of Alloy Phase Diagrams, 1984, vol. 5, pp. 74-84.

56. T. Yoshikawa and K. Morita: Yoyuen Oyobi Koon Kagaku, 2006, vol. 49, pp. 155-63. [in Japanese]

57. F. A. Trumbore: Bell System Tech. J., 1960, vol. 39, pp. 205-33.

58. M. Maeda: Seisan Kenkyu, Institute of Industrial Science at University of Tokyo, 1986, vol. 38, pp. 425-33. [in Japanese]

59. G. J. Kipouros and R. A. Sharma: J. Electrochem. Soc., 1990, vol. 137, pp. 333338.

60. T. R. Hogness: J. Am. Chem. Soc., 1921, vol. 43, pp. 1621-28.

61. G. J. Janz: J. Phys. Chem. Ref. Data, vol. 17, Supplement No. 2, American Chemical Society and the American Institute of Physics for the National Institute of Standards, New York, USA, 1988, p. 23.

62. T. B. Massalski: Binary Alloy Phase Diagrams, ASM International, Materials Park, USA, 1996.

63. J. Delcet and J. J. Egan: Metall. Mater. Trans. B, 1978, Vol. 9B, pp. 728-29.

64. M. Kato and S. Minowa: J. ISIJ, 1966, vol. 52, pp. 32-41.

65. S. Yang, X. Su, J. Wang, F. Yin, N. Y. Tang, Z. Li, and X. Li: Metall. Mater. Trans. A, 2011, vol. 42A, pp. 1785-92.

66. G. Adachi: Rare Metal Binran, Maruzen Co., Ltd., Tokyo, Japan, 2011. [in Japanese] 